Egyptian Journal of Aquatic Biology \& Fisheries

Zoology Department, Faculty of Science,

Ain Shams University, Cairo, Egypt.

ISSN $1110-6131$

Vol. 25(5): 881 - 892 (2021)

www.ejabf.journals.ekb.eg

\title{
A new record of the freshwater bivalve Pisidium amnicum (Family: Sphaeriidae) from Qena Governorate, Upper Egypt
}

\author{
Ahmed S. Moustafa and Elamier H. M. Hussien* \\ Zoology Department, Faculty of Science, South Valley University, 83523 Qena Egypt \\ Corresponding author: elameer.hussien@sci.svu.edu.eg
}

\begin{abstract}
ARTICLE INFO
Article History:

Received: Oct. 12, 2021

Accepted: Nov. 17, 2021

Online: Nov. 29, 2021

Keywords:

Freshwater Bivalvia,

Sphaeriidae,

Pisidium amnicum,

Qena Governorate,

Upper Egypt.

\section{ABSTRACT}

Family Sphaeriidae was neglected in North Africa and studies on this group of benthic organisms are very limited compared to other taxa. The originality of this work is drawn from the fact that this was the first time to record a member of the Family Sphaeriidae in Egypt. In addition, to our knowledge, this is the first record of Pisidium amnicum in Egypt. The current work was conducted to enhance the faunal knowledge and determine the actual conservation status of Genus Pisidium (Pfeiffer, 1821), Pisidium amnicum (Müller, 1774), which was collected from the River Nile in Qena Governorate. The shell of these individuals is up to $11 \mathrm{~mm}$ I length; it inhabits slow-flowing rivers; has a subtriangular shape in the adult; ornamented with very fine striations, giving it a shiny aspect. It has a thick appendicular at the top of each valve and numerous pores covering the internal surface. The hinge plate is arched but hardly or not at all thickened. These bivalves also have a relatively small outer demibranch. Although, externally, all the age classes resemble each other, the shape of their ligament-pit is different; it is either long or narrow. Data on this context is highly required to address the impact of the human increasing pressure on habitat loss and anthropogenic transformation of habitats of Pisidium amnicum in the Mideterranean biodiversity.
\end{abstract}

\section{INTRODUCTION}

The family Sphaeriidae includes the smallest freshwater bivalves and is distributed worldwide. Kuiper (1983) stated that the origin of Pisidium is certainly Mesozoic, and their centre of evolution lies without doubt in the Holarctic Region. Biodiversity of freshwater ecosystems is suffering a continuous loss reaching an alarming rate, and still limited information is known about the functional role of most of this biodiversity (Korniushin, 2000; Vaughn \& Hakenkamp, 2001). Although freshwater burrowing bivalves have the potential to strongly influence ecosystem processes, the afore- mentioned authors pointed that the ecosystem roles of burrowing freshwater bivalves have been particularly understudied.

Unfortunately, this concept is also applied to the bivalves of Africa. Research on the Spheariidae of Africa, up till the present, has been limited to a few taxonomic studies 
conducted and published many years ago. An account of the freshwater molluscs of the Belgian Congo (Pilsbry \& Bequaert, 1927) reported 9 species of Pisidium from Africa at that stage. Moreover, they predicted that Africa would doubtlessly prove to have more species of this genus when special methods for collecting aquatic minutiae are employed. It is therefore not surprising that a total of 20 species were reported for Africa by Mandahl-Barth (1988). With regard to South Africa Connolly (1939) reported the following three species of the genus Pisidium: P. ovampicum (Ancey, 1890), $P$. langleyanum (Melvill \& Ponsonby, 1891), and P. costulosum (Connolly, 1931). Two and a half decades later, seven species were reported by Kuiper (1964) in his contribution towards knowledge of the South African species of the genus Pisidium. The four additional species added to the list of Connolly (1939) by this author comprised $P$. casertanum (Poli, 1791), $P$. pirothi (Jickeli, 1881), $P$. viridarium (Kuiper, 1956), and $P$. harrisoni (Kuiper, 1964). Kuiper (1964) assumed that $P$. langleyanum, $P$. costulosum and $P$. harrisoni are Southern African endemics, while the others are also known to occur elsewhere in Africa. Another species, P. (Parapisidium) reticulatum, was reported from the Okavango Delta, Botswana (Appleton et al., 2003). In his account of the Mollusca of Southern Africa, Appleton (2002) noted that, 8 species of Pisidium have been reported from South Africa of which 6 are represented in the database of the National Freshwater Snail Collection (NFSC) of South Africa. No records have been found of either $P$. harrisoni or $P$. reticulatum in the present database.

With respect to the fact that they can utilise habitats such as springs, small creeks and peat bogs where no other bivalves can survive, Korniushin (2000) perceived the investigation of Pisidium species important, not only for understanding the structure and history of the fauna, but also because they could be used for monitoring environmental conditions. It was recorded that the representatives of this genus can serve as intermediate hosts for trematode parasites (Cannon, 1972; Rantanen et al., 1998). Nevertheless, the role of local representatives of this genus in the epidemiology of mollusc-borne parasitic diseases has not yet been investigated. Though little is also known about the conservation status of the South African Sphaeriidae, yet Herbert (1998) considered that P. harrisoni may meet the criteria for Red listing. Moreover, it was reported, elsewhere in the world, that native burrowing bivalves are declining at a catastrophic rate (Vaughn \& Hakenkamp, 2001). A significant decrease of species richness and density of gastropods and bivalves is attributed to climatic warming, a phenomenon that could be observed in the river system in France (Mouthon \& Daufresne, 2006).

This is an account of the habitats and geographical distribution of P. langleyanum, currently the Pisidium species, with the largest number of records in the database of the NFSC of South Africa. The possible effect of climatic changes on the geographical distribution of $P$. langleyanum and the conservation status of Pisidium species in South Africa was briefly discussed.

Pisidium is a genus of freshwater bivalves belonging to the family Sphaeriidae that includes the smallest bivalves on Earth. Despite their small size, Pisidium species can be used for bioindication studies (Horsák 2001). The usefulness of these species as markers of metals and organic pollution has been proved repeatedly (Ingram et al., 1953; Wurtz, 1955; Anderson, 1977; Gadzała-Kopciuch et al., 2004; Alhejoj et al., 2017).

This genus is cosmopolitan and occurs in temporary and permanent aquatic environments. Along with Dreissenidae, Sphaeriidae is the only family of bivalves 
inhabiting subterranean habitats (Culver 2012; Prié 2019). Their occurrence in caves has been reported by a number -albeit few- of authors from different localities; Pisidium casertanum (Poli, 1791), Pisidium personatum (Malm, 1855) from Scotland (Knight, 2018 and Knight \& Wood, 2000), Pisidium zoctanum (Poli, 1876), Sphaerium tasmanicum (Woods, 1876) from Australia (Kuiper, 1983 and Korniushin, 2000), Pisidium crimeana (Stadnichenko, 1980) from Ukraine (Vargovitsh and Anistratenko 2016 \& Vinarski and Kantor 2016), Pisidium subterranea (Zhadin, 1932) from Caucasus (Vinarski \& Kantor, 2016 and Voode, 2017), Pisidium cavatica (Zhadin, 1952), Pisidium ljovushkini (Starobogatov, 1962) and Pisidium hallae (Kuiper, 1983).

In North Africa, studies on the freshwater clams are still rare. Notably, in Morocco, few studies have been conducted on the distribution of Pisidium species, where only seven species were reported (Kuiper, 1972) and extreme environments, such as caves were not prospected (Rassam $\boldsymbol{e t}$ al., 2020).

A review of the recent literature on the freshwater malacofauna in Egypt has shown that family Sphaeriidae was not considered to be represented in the molluscan fauna of Egypt (Damme, 1984; Neubert, 1998; Brown, 2005; Ibrahim et al., 2006; Thompson et al., 2009; Hussein et al., 2011; Abd Elwakeil et al., 2013; Choubisa \& Sheikh, 2013; Abdel - Gawad \& Mola, 2014; Lotfy \& Lotfy, 2015).

The aim of this paper was to record for the first time the occurrence of Sphaeriidae species in Upper Egypt and to describe the particularities of these individuals that have not yet been mentioned.

\section{MATERIALS AND METHODS}

The present study was carried out in the faculty of Science at Qena city, South Valley University, Egypt. Six valve specimens of pisidium sp. were collected from the River Nile at Qena city $\left(26.17^{0} \mathrm{~N}, 32.7^{0} \mathrm{E}\right)$ during spring 2019.

In nature, the snails were found in common association with one or more other molluscan bivalve's genera.

This work is the first step towards future exploration of Sphaeriidae in Egypt.

The shells were examined under microscope. The valves were then immersed in a bath of 5\% commercial Chlorox (sodium hypochlorite) to dissolve the remaining organic matter, washed in a solution of distilled water and dried at room temperature before being coated and examined by SEM.

For the identification of the different parts of the sphaeriid shells, the terminology adopted in the study of Kuiper (1983) was used as follows: 


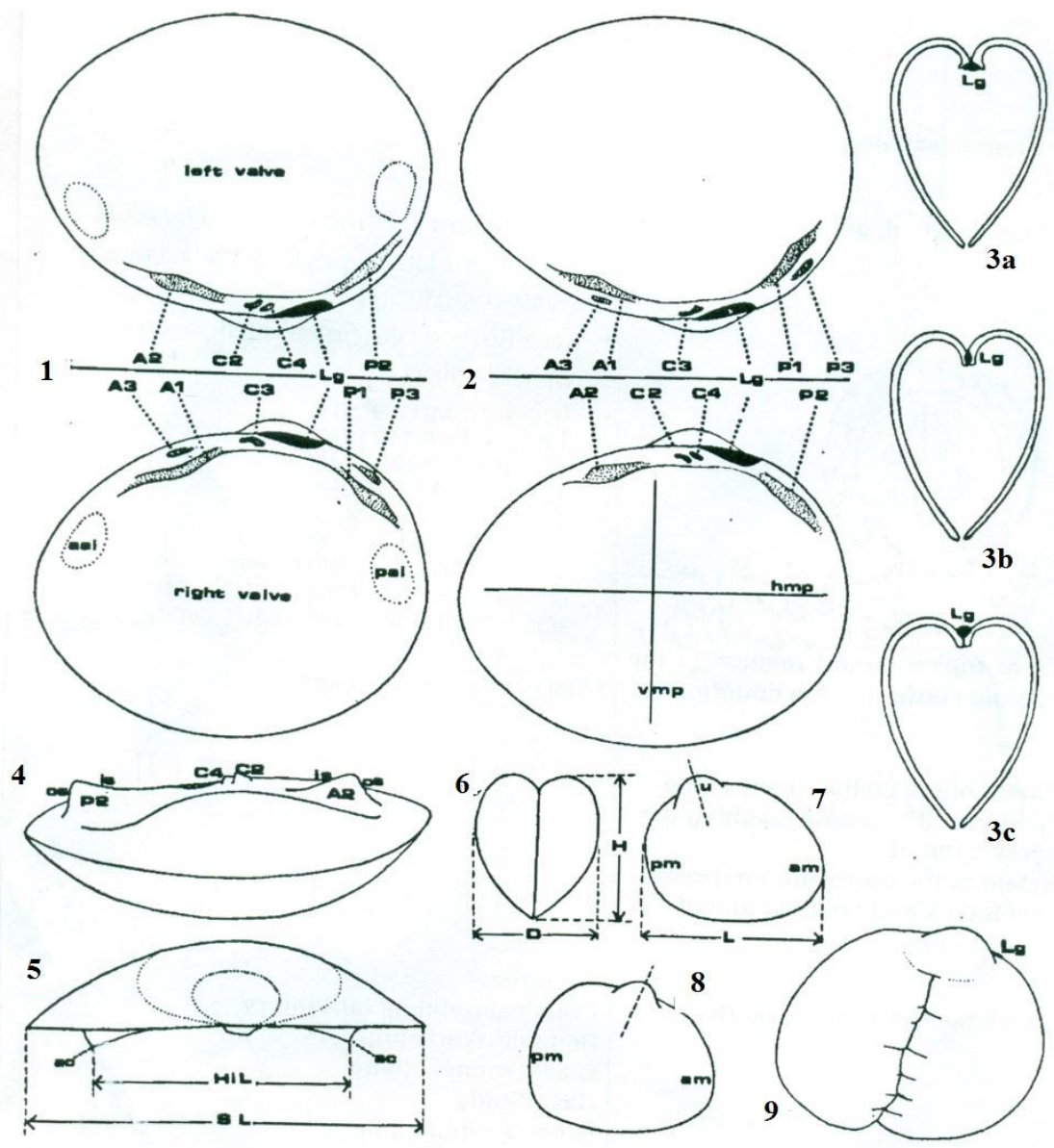

Fig. 1. Terminology of sphaeriid shells. - 1, Dentition: AI, A2, A3, anterior lateral teeth; C2, C3, C4, cardinal teeth; PI, P2, P3, posterior lateral teeth; Lg, ligament and ligament-pit. Adductors: aai, anterior adductor impression; pai, posterior adductor impression. - 2, Reversed dentition. Median plans: vmp, vertical median plan; hmp, horizontal median plan. - 3, Situation of ligament (Lg) and ligament-pit: Sa, introverted; Sb, enclosed; $S e$, extraverted ligament-pit and protruding ligament. - 4, Ventral view on hinge, left valve: is, inner or proximal slope of laterals; os, outer or distal slope of laterals. - 5, Measuring of ratio hinge-length (HiL) and shell-length (SL); ac, apex or cusp. - 6, Height index (H.i.) = 100.H:L. Convexity index $(\mathrm{Cl}$.) of single valve: 100.D:2H. Descriptive terms of convexity: C.I. inferior to $30=$ shell flat or compressed; C.i. between 30 and $40=$ moderately or slightly convex, tumid, swollen; CJ. between 40 and $\mathrm{SO}=$ inflated, globose, globular or ventricose; C.i. more than $S O=$ very or extremely tumid, inflated or ventricose. - 7, Beak or umbo (u) inclined backward (opisthogyrous); am, anterior or front margin of the shell; pm, posterior margin. -8 , Beak inclined forward (prosogyrous). -9 , Diphyoidic shell.

\section{RESULTS AND DISCUSSION}

The physical factors were recorded where the water temperature ranged from 15 to $28.5^{\circ} \mathrm{C}, \mathrm{pH}$ ranged from 6.74 to 7.8 , dissolved Oxygen ranged from 5.4 to $7.6 \mathrm{ppm}$, conductivity ranged from 0.22 to $0.98 \mathrm{~ms}$ and TDS ranged from 150 to $890 \mathrm{mg} / \mathrm{L}$.

Morphological studies of the shell of the collected specimens revealed that the individuals belonging to one species of genus Pisidium.

Genus Pisidium are small bivalves (usually $<10 \mathrm{~mm}$ ) that belong to the subfamily, Sphaeriinae, family Sphaeriidae; Superfamily, Sphaerioidea; Order, Sphaeriida;, Superorder, Imparidentia; Subterclass, Euheterodondata; Infreaclass, Heterconchia; 
Subclass, Autobranchia; Class, Bivalvia. They inhabit fine deposits in a variety of freshwater ecosystems. The shells of some of the species of these bivalves present considerable variation, most often linked to the hydrological and physico-chemical characteristics of the environment in which they live (Saunders \& Kling, 1990; Funk \& Reckendorfer, 2008).

This phenomenon is particularly remarkable in Pisidium casertanum (Poli, 1791), being the most common and cosmopolitan of the genre, and raising one of these alleged forms or varieties to species rank that often gives rise to debate (Dyduch-Falniowska, 1983; Kuiper, 1983; Piechocki, 1989; Araujo \& Korniushin, 1998; Gloer \& Zettler, 2005). On the contrary, polymorphism is quite limited in other species such as Pisidium henslowanum (Sheppard, 1823), P. supinum (Schmidt, 1851) or P. milium (Held, 1936). For several years, shells with an appendiculum (a more or less oblique fold located close to the top of each valve) resembling $P$. supinum or forma plicata of $P$. casertanum (Zeissler, 1962) have been observed in rivers and canals, but they present specific characters. To fix the identification, the collected species need a lot of studies including anatomy of the soft parts and molecular.

\section{DESCRIPTION}

The shell of these individuals has a subtriangular shape in the adult (Fig. 2), ornamented with very fine striations, giving it a shiny aspect, a thick appendiculum at the top of each valve and numerous pores covering the internal surface (Fig. 5). The hinge plate is arched but, hardly or not at all, thickened (Figs $4 \& 5$ ). Morphometric results of the six specimens collected showed that they have a length ranging between 3.49 and $1.91 \mathrm{~mm}$ and height between 2.93 and $1.62 \mathrm{~mm}$. The shell is silky with slight striations, and the umbo is narrow and located posteriorly. The shape of the shell is sub-angulated; the most extreme point of the anterior part is located lower than the middle of the shell height. The anterior part is clearly longer than the posterior part. The hinge is thicker, more or less wide. The ligament pit is long. The left valve has two long cardinal teeth, the lower (C2) and the uppermost (C4) are parallelly located, C4 overlaps C2 at anterior end, $\mathrm{C} 3$ is long and slightly curved. All individuals found in the present work are exactly similar to the description given by other authors (Adam, 1960; Piechocki, 1989; Killeen et al., 2004) (Figs.4 \& 5).

These bivalves also have a relatively small outer demibranch (Korniushin \& Hackenberg, (2000). Although, externally, all the age classes resemble each other, the shape of their ligament-pit is different; being long and narrow in the present species. Comparing this criterion and the shape of the shell of the present species with the most closely $P$. supinum and $P$. casertanum forma ponderosa, the results revealed difference in the length of ligament and shape of shell. On the other hand, comparing these results with those of $P$. amnicum described in the studies of Timm (1975, 1976), Kuiper (1983), Korniushin $(1991,1996,2002)$ and Voode (2017); the present species found in Egypt are confirmed to be Pisidium amnicum. 


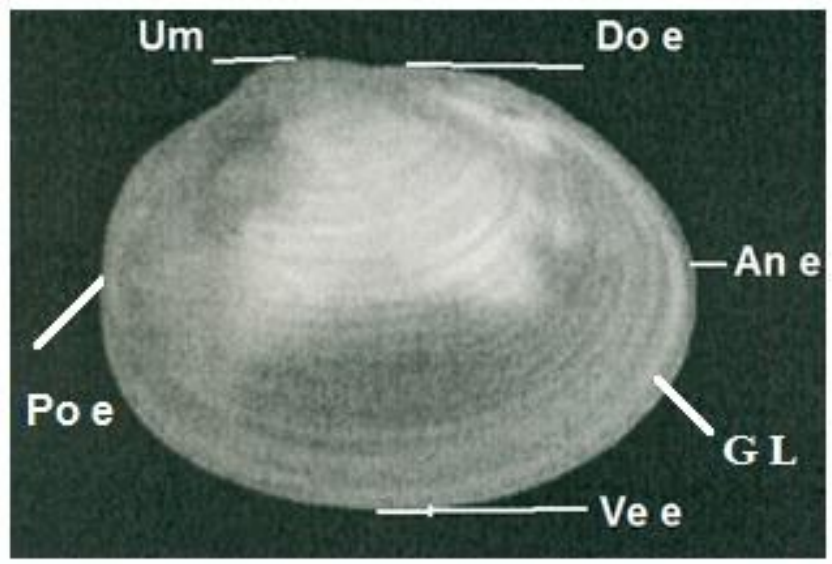

Fig. 2. Lateral view of the left valve of Pisidium amnicum showing the smooth structure of the exterior surface (um= Umbo; Do e= Dorsal end; An e=Anterior end; Ve e= Ventral end; Po e= Posterior end and G L= Growth Lines $).(1 \mathrm{~cm}=1 \mathrm{ml})$

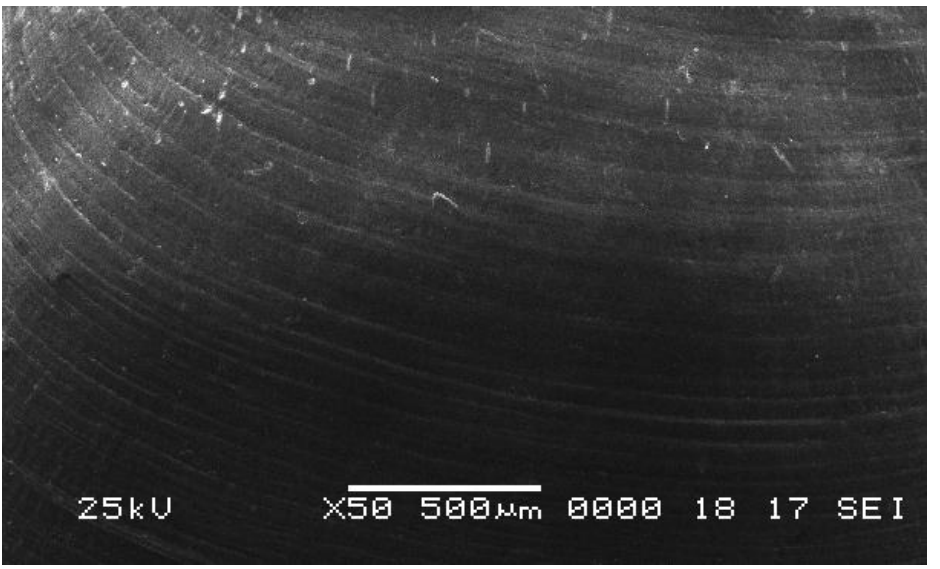

Fig. 3. SEM of the surface of valve of Pisidium amnicum showing very fine growth lines
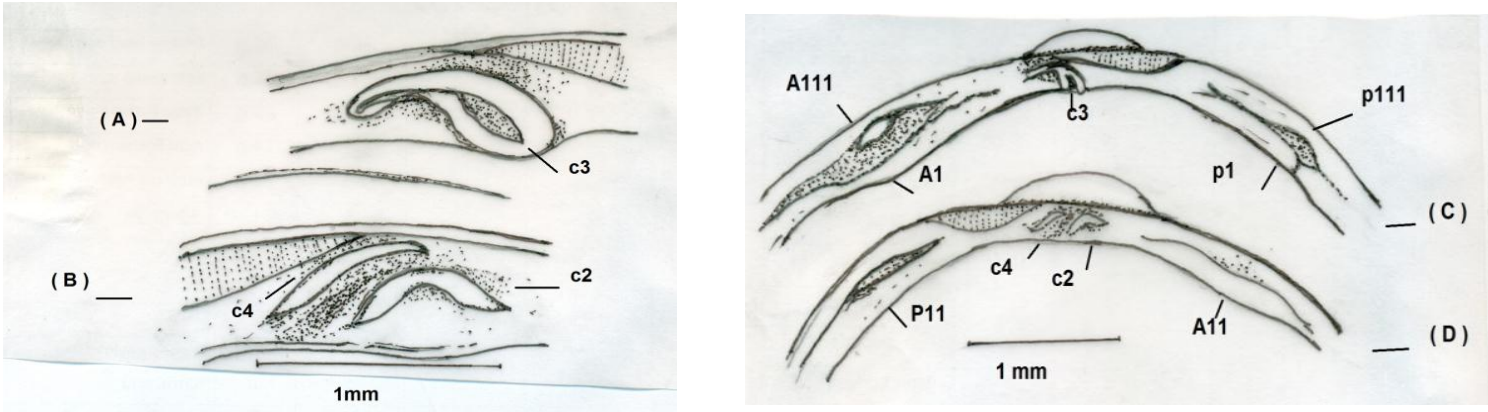

Fig. 4. Diagrammatic drawing of the hinge teeth of Pisidium amnicum: (A) C3 - cardinal tooth of the right valve; (B) C2, C4 - cardinal teeth of the left valve; (C) AI, AIII - anterior lateral teeth of the right valve; PI, PIII - posterior lateral teeth of the right valve; (D) AII anterior lateral tooth of the left valve; PII - posterior lateral tooth of the left valve. 
Terminology adapted from Timm (1975)
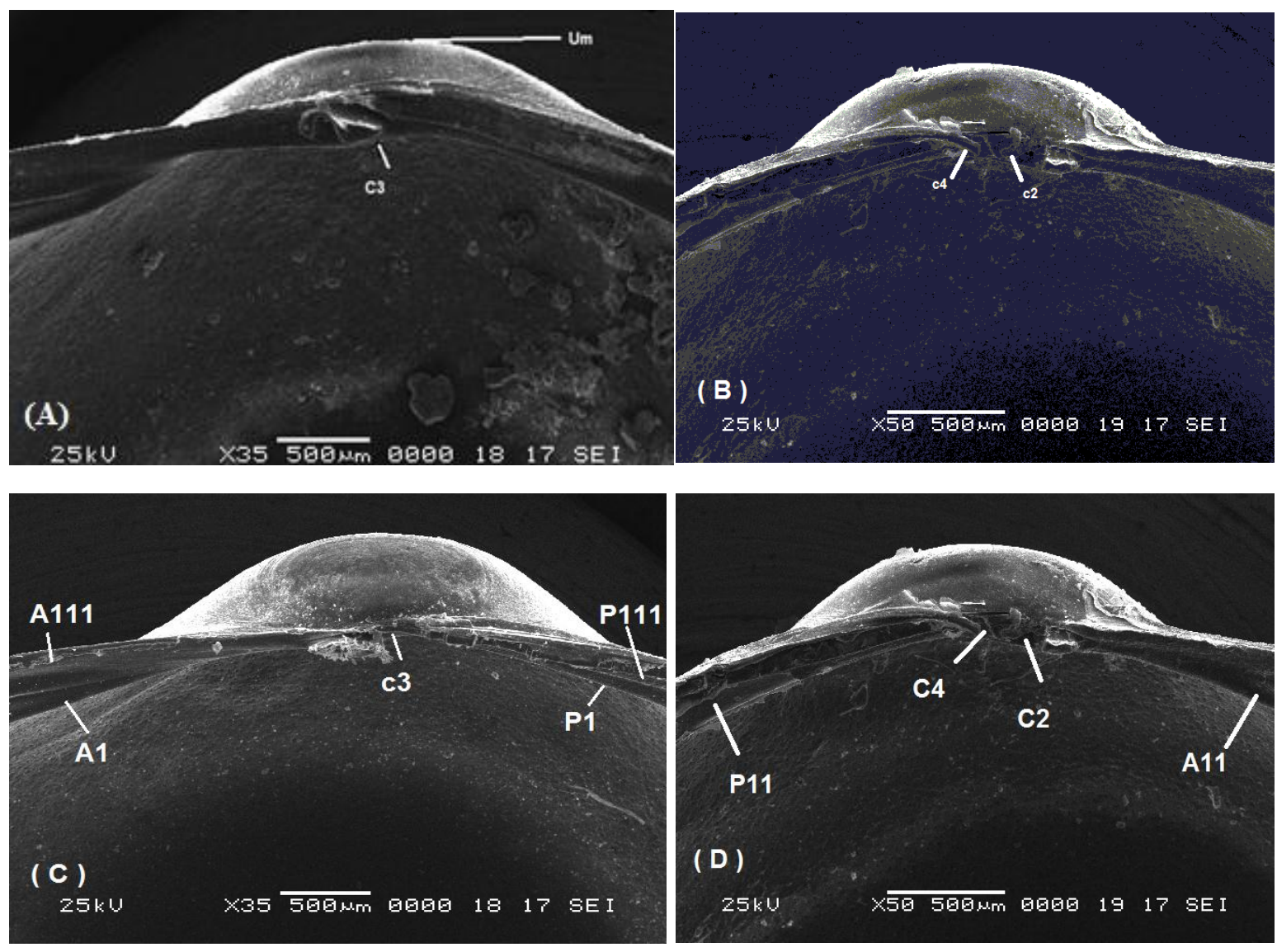

Fig. 5 SEM of the hinge teeth of Pisidium amnicum: (A) C3 -cardinal tooth of the right valve; (B) C2, C4 - cardinal teeth of the left valve; (C) AI, AIII - anterior lateral teeth of the right valve; PI, PIII - posterior lateral teeth of the right valve; (D) AII - anterior lateral tooth of the left valve; PII - posterior lateral tooth of the left valve. Terminology adapted from Timm (1975)

\section{CONCLUSION}

In general, the Sphaeriidae family is neglected in North Africa, and studies on this group of benthic organisms are very limited compared to other taxa. The originality of this work consists in recording, for the first time, a member of the Sphaeriidae family in North Africa from the River Nile at Qena Governorate, Egypt, and to the best of our knowledge; it is the first record of P.amnicum. This is important in order to enhance our faunal knowledge and to determine the actual conservation status of Pisidium species. Moreover, this need becomes urgenly recommended to address the human increasing pressure, including habitat loss and anthropogenic transformation of habitats of Pisidium species (e.g. rivers, lakes and springs) in a Mediterranean biodiversity. 


\section{REFERENCES}

Abd El-wakeil, K. H., Obuid-Allah, A. H., Mohamed, A. H, and Abd El-aziz, F. E. (2013). Community structure of mollscans in River Nile and its branches in Assiut Governorate, Egypt. Aquatic Research, 39: 193 - 198.

Abdel - Gawad, S. S. and Mola, H. R. A. (2014). Macrobenthic inveretebrates in the main channel of Lake Nasser, Egypt. Egypt. J. Aqu. Res., 40: 405 - 414.

Adam, W. (1960): Faune de Belgique: Mollusques Terrestres et Dulcicoles. Institut Royal des Sciences Naturelles de Belgique, Bruxelles, 402 pp.

Alhejoj, A.; Bandel, K. and Salameh, E. M. (2017). Aquatic Mollusks: Occurrences, Identification and Their Use as Bioindicators of Environmental Conditions (Salinity, Trace Elements and Pollution Parameters) in Jordan. Water Ressources in Arid Areas: The Way Forward. Springer Water, pp.295-318. Https://doi.org/10.1007/978-3-31951856-5_17

Ancey, D. F. (1890). Nouvelles contributions malacologiques XIII. Mollusques nouveaux de l`' Afrique austral et occidentale. Bull. Soc. Malac. France 7: 156:162.

Anderson, R. V. (1977). Concentration of cadmium, copper, lead, and zinc in six species of freshwater clams. Bulletin of Environmental Contamination and Toxicology 18: 492496. Https://doi.org/10.1007/BF01683722

Appleton, c. c. (2002). Mollusca. In: De Moor IJ and Day JA (eds.) Guides to the Freshwater Invertebrates of Southern Africa. Volume 6, Chapter 3: Arachnida \& Mollusca, Araneae, Water Mites \& Mollusca. WRC Report No 182/02. Water Research Commission, Pretoria, South Africa. Pp 42-125.

Appleton, c. c.; Curtis, B. A.; Alonso, L. E. and Kipping, J. (2003). Freshwater invertebrates of the Okavango Delta, Botswana. In: A rapid Biological Assessment of the Aquatic Ecosystems of the Okavango Delta: High Water Survey. RAP Bull. Biol. Ass. 27 $58-68 ; 123-136$

Araujo, R. and Korniushin, A. V. (1998). Microsculpture of Pisidium casertanum (Poli, 1791) and some related species and forms (Bivalvia: Sphaeriidae). Malak. Abh. Mus. Tierkd. Dresden 19(7): 59-69.

Brown, D. (2005). Freshwater snails of Africa and their medical importance. Taylor \& Francis publishers.

Cannon, I. R. G. (1972). Studies on the ecology of the papillose allocreadiid trematodes of the yellow perch in Algonquin Park, Ontario. Can. J. Zool. 50 1231-1239.

Choubisa, S. L. and Sheikh, Z. (2013). Freshwater snail (mollusca - gastropoda) as bioindicator for diverse ecological aquatic habitats. Cibtech J. Zool., 3(3): 21-25. 
Connolly, M. (1931). Description of new non-marine Mollusca from North, South and central Africa, with notes on other species. Ann. Mag. Nat. Histo. 10, 8: 305-322.

Connolly, M. (1939). A monographic survey of the South African non-marine Mollusca. Ann. S. Afr. Mus. 33 1-660

Culver, D. C. (2012). Mollusks Encyclopedia of Caves (2nd edn.). American University, 512-517. Https://doi.org/10.1016/B978-0-12-383832-2.00074-8

Damme, D. van (1984). The freshwater mollusca of northern Africa, Distribution, biogeography and palaeoecology. Dr. W. Junk publishers.

Dyduch-Falniowska, A. (1983). Shell microstructure and systematics of Sphaeriidae (Bivalvia: Eulamellibranchiata). - Acta Zoologica Cracoviana 26: 251-296.

Funk, A. and Reckendorfer, W. (2008). Environmental heterogeneity and morphological variability in Pisidium subtruncatum (Sphaeriidae, Bivalvia). International Revue of Hydrobiology 93: 188-199.

Gadzała-Kopciuch, R.; Berecka, B.; Bartoszewicz, J. and Buszewski, B. (2004). Some considerations about bioindicators in environmental monitoring. Polish Journal of Environmental Studies 13: 453-462.

Glöer, P. and Zettler, M. L. (2005). Kommentierte Artenliste der Süsswassermollusken Deutschlands. - Malakologische Abhandlungen 23: 3-26.

Herbert, D. G. (1998). Molluscan conservation in South Africa: diversity, issues and priorities. J. Conchol. Spec. Publ. 2 61-76.

Holopainen, I. J. and Hanski, I. (1986). Life history variation in Pisidium (Bivalvia: Pisidiidae). - Holarctic Ecology 9: 85-98.

Horsák, M. (2001). Současný stav našich hrachovek (Pisidium) a možnosti jejich využití $\mathrm{v}$ bioindikaci [The present status of our pill clams and possibilities of their application in bioindication]. Ochrana prírody 56: 53-56.

Hussein, M. A., Obuid-Allah, A. H.; Mahmoud, A. A. and Fangary, H. M. (2011). Population dynamics of freshwater snail (Mollusca: Gastropoda) at Qena Governorate, Upper Egypt. Egypt. Acad. J. Biology. Sci., 3(1): 11 - 22.

Ibrahim, M. I. M.; Shalaby, I. M. I. and Salem, M. A. M. (2006). Freshwater snails and larval trematode communities in Al-Salam irregation canal. Egypt. J. Zoology, 47: 65 -81 .

Ingram, W. M.; Ballinger, D. G. and Gauffin, A. R. (1953). Relationship of Sphaerium solidulum Prime to organic pollution. Ohio Journal of Science 53: 320235. Https://doi.org/10.1111/j.1949-8594.1953.tb07008.x 
Jickeli, C. F. (1881). land-und susswasser-Conchylien Nordost Afrikas. Jb. Dtsch.

Malak. Ges. 8: 336-340.

Killeen, I.; Aldridge, D. and Oliver, G. (2004). Freshwater Bivalves of Britain and Ireland. Field Studies Council ( $1^{\text {st }}$ edn. $), 119$ pp.

Knight, 1. (2018). The aquatic invertebrate fauna of selected Scottish caves. The Grampian Speleological Group Bulletin 2: 19-37.

Knight, l. and wood, P. J. (2000). Bivalves (Pisidiidae) in English caves. Cave and Karst Sciences 27: 89-90.

Korniushin, A. V. (1998). On the identity of the anatomically distinct form of Pisidium casertanum (Poli) (=P. Roseum sensu Korniushin 1995). - Heldia 2 (5/6): 133-135.

Korniushin, A. V. (2000). Review of the family Sphaeriidae (Mollusca: Bivalvia) of Australia, with the description of four new species. Records of Australian Museum 52: 41-102. Https://doi.org/10.3853/j.0067-1975.52.2000.1308

Korniushin, A. V. and Hackenberg, E. (2000). Verwendung konchologischer und anatomischer Merkmale für die Bestimmung mitteleuropäischer Arten der Familie Sphaeriidae (Bivalvia), mit neuen Bestimmungschlüssel und Diagnosen. Malakologische Abhandlungen 20 (6): 45-72.

Kuiper, J. G. J. (1972). Une récolte de Pisidium dans le Moyen Atlas. Résultats de la mission biologique au Maroc de l'Université de Gand, Belgique. Basteria 36: 2-5.

Kuiper, J. G. J. (1983). The Sphaeriidae of Australia. Basteria 47: 3-52.

Lotfy, W. M. and Lotfy L. M. (2015). Synopsis of the Egyptian freshwater snail fauna. Folia Malacologica 23(1): 19 - 40.

Mallet, J. (2007). Hybrid speciation. - Nature 446: 279-283.

Malm, A. W. (1855). Om sveska landt-orch sÖtvattens-molluske. GÖteb. K. Vet. Vitt.

Samh. Handl. 3: 77-152.

Mandahl-Barth, G. (1988). Studies on African Freshwater Bivalves. Charlottenlund, Denmark: Danish Bilharziasis Laboratory. 161 pp.

Mouthon, j. and Daufresne, M. (2006). Effects of the 2003 heatwave and climatic warming on mollusc communities of the Saône: a large lowland river and of its two main tributaries (France). Global Change Biol. 12 441-449

Mouthon, J. and Kuiper, J. G. J. (1987). Inventaire des Sphaeriidae de France. Secrétariat Faune-Flore, Muséum National d'Histoire Naturelle 41: 1-60. Paris.

Mouthon, J., (2011). Response of bivalve populations to drying disturbance and life history traits of two Pisidium species (Bivalvia: Sphaeriidae) in a reservoir of the French 
Upper Rhone river. - Annales de Limnologie - International Journal of Limnologie 47: 175-184.

Müller, O. F. (1774). Vermivm terrestrium et fluviatilium, seu Animalium infusiorum, helminthicorum, et testaceorum, non marinorum, succincta historia. Volumen alterum. Heineck et Faber, Havniae [= Copenhagen] et Lipsiae [= Leipzig], xxxv, 214 [10] pp.

Neubert, E. (1998). Annoted checklist of the terresterial and freshwater mollusca of the Arabian peninsula with a description of new species. Fauna of Arabia, 17: 333 - 461.

Pantanen, J. T.; Valtonen, E. T. and Holopainen, I. J. (1998). Digenean parasites of the bivalve mollusk Pisidium amnicum in a small river in eastern Finland. Dis. Aquat. Org. 33:201-208.

Piechocki A (1989). The Sphaeriidae of Poland (Bivalvia, Eulamellibranchia). Annales Zoologici 24: 249-320.

Pilsbry, H. A. and Bequart, J. (1927). The aquatic mollusks of the Belgian Congo, with a geographical and ecological account of Congo malacology. Bull. Am. Mus. Nat. Hist. 53:69-602.

Prié, V. (2019). Molluscs. In: White W, Culver D, Pipan T (Eds) Encyclopedia of Caves. 725-731. Https://doi.org/10.1016/B978-0-12-814124-3.00087-X

Rassam, H.; Moutaouakil, S.; Benaissa, H.; Albrecht, C. and Ghamizi, M. (2020).First record of Pisidium subtruncatum Malm, 1855 (Bivalvia, Spheriidae) in an African cave, Subterranean Biology 34:99-108.

Saunders, J. F. and Kling, G. W. (1990). Species distribution and shell characteristics of Pisidium (Mollusca: Bivalvia). - Freshwater Biology 24: 275-285.

Thompson, G.T; Heyn, W. M. and Campbell, D. N. (2009). Thiara Scabra (O. F. Muller, 1774): The introduction of another Asian freshwater snail into the United States. The nautilus, 123(1): 21 - 22.

Timm, V. (1975). The pisidiinae and the Euglesinae of the Lake Võrtsjärv. In: Frey T. et al. (Eds.) Productivity of Estonian water bodies. Estonian Contributions to the International Biological programme, 6: 201-261.

Timm, V. (1976). On the pisidiidae of Lake Peipsi-phkva. Esti NSV Teaduste Akadeemia Toimetised: Bioloogia, 25(1):37-52.

Vargovitsh, R. S. and Anistratenko, V. V. (2016). "Pisidium zoctanum Poli, 1876" (Mollusca, Bivalvia) - a ghost-taxon from the Crimean Karani-Koba Cave. Ruthenica 26: 171-174.

Vaughn, C. C. and Hakenkamp, C. C. (2001). The functional role of burrowing bivalves in freshwater ecosystems. Freshwater Biol. 46 1431-1446.

Vinarski, M. V.; Kantor, Y. I. (2016). Analytical catalogue of fresh and brackish water molluscs of Russia and adjacent countries. KMK Scientific Press, Moscow, 544 pp. 
Voode, M. (2017): Taxonomic status of Pisidium ammicum (Muller, 1774) and $P$. inflatum Megerle von MÜhlfeld in porro, 1838 (Mollusca: Bivalvia : Sphariidae), Ruthenica, vol. 27 No. 1:39-49.

Wallbrink, H. (1995). Een opmerkelijke vondst in de Nieuwe Merwede: Pisidium casertanum plicatum Zeissler, 1962 [A remarkable discovery in the new Merwede: Pisidium casertanum plicatum Zeissler, 1962]. Correspondentieblad van de Nederlandse Malacologische Vereniging 284: 61-65

Wurtz, C. B. (1955). Stream biota and stream pollution. Sewage and Industrial Wastes 27: 1270-1278.

Zeissler, H. (1962). Die Mollusken aus der zentralen Torfschicht des Köpenicker Burggrabens In: Hermann J, "Köpenïck", Ergebnisse der Archäologischen Stadtkernforschung in Berlin 12(4): 103-106.

Zeissler, H. (1971). Bestimmungstabelle für die Mitteleuropäischen Sphaeriaceae. Limnologica 8(2): 453-503. 